\title{
The Application of Traditional Chinese Elements in Luxury Fashion Goods
}

\author{
Leilei Jia ${ }^{1,2 *}$ and Hui'e Liang ${ }^{1,2,3}$ \\ ${ }^{1}$ College of Textile and Clothing, Jiangnan University, China \\ ${ }^{2}$ Jiangsu Intangible Cultural Heritage Research Base, China \\ ${ }^{3}$ Wuxi Institute of Arts and Technology, China
}

*Corresponding author: Leilei Jia, College of Textile and Clothing, Jiangnan

University, Wuxi, China.

Received Date: December 03, 2018

Published Date: December 05, 2018

\section{Introduction}

With a fast-growing economy and a massive population, Chinese consumers' purchasing power in the luxury market is increasing to the extent that China has managed to become the most attractive markets for luxury brands in the world, especially in the consumption of fashion brands.

The word luxury comes from the Latin word "Luxus", which means indulging the senses, regardless of cost [1]. Luxury brands where most of their products are luxury goods [2]. Luxury goods often have high brand perception quality, with high price, high quality, beautiful design, inheritance, reputation, unique and individual characteristics. Luxury goods can provide consumers with prestige and social status [3].

According to the data, the more popular luxury fashion brands are: Hermes, Ermenegildo Zegna, Giorgio Armani, GUCCI, Prada, Chanel, Versace, Ferragamo, Christian Dior, Louis Vuitton, Burberry, and Fendi, Yves Saint Laurent.

A director of the Boston Consulting Group pointed out that major luxury brands are trying to please Chinese consumers [4], whether to improve the supply of core products to Chinese stores, or to launch Chinese-style products in accordance with the Lunar New Year. Therefore, the ability to timely explore Chinese consumer preferences and demand will directly affect the performance of luxury brands.

These luxury fashion brands have increased their Chinese market. In terms of product strategy, the following two points should be achieved: First, creativity is essential: luxury goods must use new design ideas and inspiration to attract consumers. The needs and business opportunities are closely related. Therefore, luxury fashion brands This will increase research efforts in the Chinese market to gain an in-depth understanding of the Chinese luxury market. Second, in order to be closer to and cater to Chinese consumers, these luxury brands have put a lot of Chinese elements into their designs and apply "Chinese style" to cater to Chinese consumers.

January and February of each year will become the "Chinese season", because many big brands will at this time promote their own classic products with "mixed" Chinese elements. For example, cosmetic products such as Givenchy, Armani, YSL, Lancome, Chanel and other brands will apply "Chinese red" and "Chinese Zodiac" elements to their products.

There are many applications of traditional Chinese elements in the clothing products of luxury brands, which are mainly reflected in the following four aspects.

\section{Structure}

Gucci's current creative director, Alessandro Michele, is a fan of Chinese style. From the Spring/Summer 2016 collection to the 2018 Early Spring collection, they are all by various Chinese elements. For example, Chinese clothing silhouette, stand collar, front opening structure, Side slits.

\section{Color}

Chinese traditional color is very unique. Mysterious and pluralistic Oriental paintings are always fascinating, with strong or elegant colors, colliding with unique charm, unique poetic ancient paintings and exotic texture stripes. In terms of color, it uses contrast color, earth color, and purple red to deduce a unique cultural collision, which is unique and mysterious and changeable.

\section{Pattern}

Dragon, Xiangyun, crane and other elements from Chinese style are also a hot fashion focus in the West. Fashion circles have 
never lacked creativity in the interpretation of dragon and tiger patterns. The span and strong impact of elements with Chinese characteristics integrated into Western carriers give people a of dragon and tiger fighting and standing on top.

Flowers, birds, insects and fish in nature are bright in color and vivid in shape. They are integrated into fashion accessories, and the vivid spring up. Tranquil, comfortable and pleasant are the most meaningful experiences for the elements of flowers and birds. Similarly, when applied to contemporary fashion, the feeling of integration of Chinese and Western styles is so unique.

\section{Ornament}

Embroidery and disc buttons are the most widely used elements in garment decoration.

As decoration, embroidery has high aesthetic and ornamental value, its own concave and convex special texture effect, making clothing more three-dimensional. Embroidery is the most frequently used Chinese element in luxury fashion products. There are six different types of embroidery used: color embroidery, bamboo stem embroidery, carving embroidery, patch embroidery, pearl embroidery, and ribbon embroidery.

Chinese traditional elements have a profound cultural heritage and broad re-creation space, which is an inexhaustible source of creativity for Chinese and foreign fashion designers. This article holds that the perfect integration of traditional Chinese elements into luxury fashion products and the design of creativity national and international clothing are of great significance to enhance the cultural value of clothing, meet the needs of fashion consumption, create brand, and open up the international market.

\section{Acknowledgement}

None.

\section{Conflict of Interest}

No Conflict of Interest.

\section{References}

1. Salehzadeh R, Pool JK (2017) Brand attitude and perceived value and purchase intention toward global luxury brands. Journal of International Consumer Marketing 29(2): 74-82.

2. Cheema $T$ (2018) Fast-fashion meets social networking users: implications for international marketing strategy. Digital Marketing Strategies for Fashion and Luxury Brands IGI Global: 1-27.

3. Zhan L, He Y (2012) Understanding luxury consumption in China: consumer perceptions of best-known brands. Journal of Business Research 65(10): 1452-1460.

4. Sisi D (2018) China luxury report: Digital and new revolution of generation Y. Fortune China. 